\title{
Research on geothermal distribution of Hongtoushan underground metal mine
}

\author{
Jingxian Liu ${ }^{1, \mathrm{a}}$,Ning Mao ${ }^{1, \mathrm{~b}}$, Xiaosong $\mathrm{Chen}^{1}$ and Deqiang Chang ${ }^{1, \mathrm{c}}$ \\ ${ }^{1}$ College of Resources and Civil Engineering, Northeastern University, Shenyang,110004,China

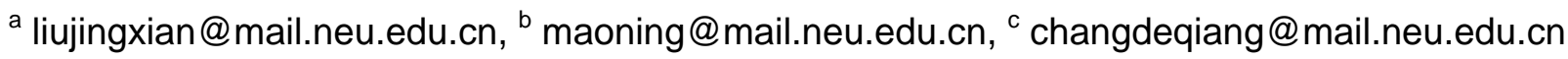

Keywords: Mine, Geothermal distribution, Geothermal gradient, Ventilation.

\begin{abstract}
With the increase of mining depth, geothermal effects become more and more serious. In the paper,temperature of original rock in Hongtoushan mine are tested, and relation between the temperature and depth, temperature and ventilation are studied. The data show that, for Hongtoushan mine, the geothermal gradient is $1.6 \mathrm{C} / 100 \mathrm{~m}$, Cooling depth of ventilation is $20 \mathrm{~m}$, rock temperature reach $30 \mathrm{C}$ at $-827 \mathrm{~m}$ level.
\end{abstract}

\section{Introduction}

With the development of mineral resources, more and more superficial deposits are dug and consumed, the depth of mine increase rapidly in China[1][2]. Now, lots of mine belong to deep mine. As the increase of depth, the geothermal effect on people become serious[3-5]. The research on geothermal distribution may help making suitable technical measures to prevent geothermal hazard in underground mine.

Hongtoushan underground metal mine(Copper and zinc) located in cold district of northeastern China, that is fushun city, liaoning province, $200 \mathrm{~m}$ to $400 \mathrm{~m}$ above sea level, annual average temperature 7.6C. The Hongtoushan mine has been running for more than 50 years, and now extend to level of $-827 \mathrm{~m}$, about $1200 \mathrm{~m}$ in depth. As an extension of the mining depth, the problem of geothermal become more and more prominent. Research on geothermal appear necessary.

\section{Geothermal distribution model}

Before cooling and heating by the outside air, the temperature of rock at constant temperature zone increase with the depth from earth's surface. The formation between rock temperature and depth is listed in the follow:

$$
\boldsymbol{t}_{n}=\boldsymbol{t}_{a}+\frac{\boldsymbol{H}-\boldsymbol{H}_{a}}{\boldsymbol{g}_{r}}
$$

Here: $t_{n}$ - the temperature of rock located in $H(m)$ below the earth's surface,C;

$t_{a}$-the temperature of rock at constant temperature zone,C;

$\mathrm{H}$ - the depth from rock to earth's surface, m;

$\mathrm{H}_{\mathrm{a}}$ - the depth of constant temperature zone, m;

$\mathrm{g}_{\mathrm{r}}$ - geothermal gradient, i.e. The increasing depth $(\mathrm{m})$ for rock temperature increase $1 \mathrm{C}$, $\mathrm{m} / \mathrm{C}$.

For several metal underground mine in Liaoning province, the geothermal gradient is about 44 57 $\mathrm{m} / \mathrm{C}$. 


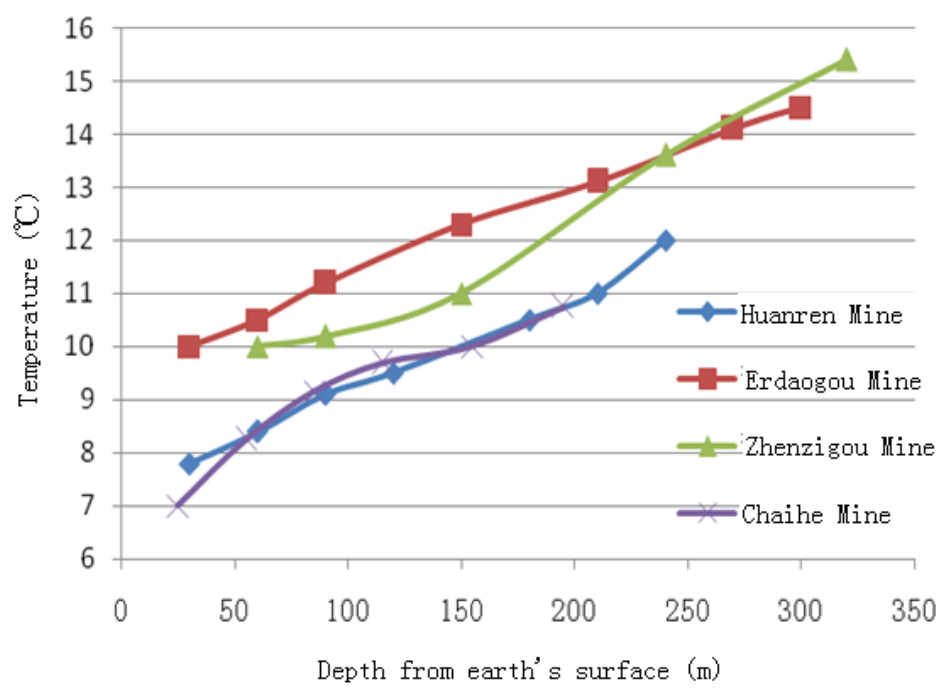

Figure 1 Relation between rock temperature and depth from earth's surface for several metal in Liaoning province

\section{Test of geothermal data}

The method of deep hole are used for geothermal data test. The drilling machine are used to drill horizontal deep hole into surrounding rock, the depth of hole should be greater than cooling depth of ventilation in tunnel. Thermocouple probe with long wire plug into and location at the bottom of hole, keep the test end of wire out of the hole. The hole should be sealed, after some time, thermometer connect with wire end, the rock temperature are tested.

In the experiment, the level of $-527 m,-587 m,-647 m,-707 m,-767 m,-827 m$ are selected to be studied. Two hole at least $30 \mathrm{~m}$ in depth are used to plug two thermocouple probes. Keep the hole dry and no water. The hole should be far away from (> $30 \mathrm{~m}$ ) the shaft, the wind well, cavity, cavern and other structures which may affect the origin rock temperature.

Plug thermocouple probe into the hole, no less than $25 \mathrm{~m}$ in depth, sealed with mud. 24 hours later, the data about temperature, location of hole, depth from earth's surface are recorded, as listed in table 1. With the data, the relation curve between rock temperature and depth increasing are shown in figure 2 .

Table 1 Geothermal data in Hongtoushan underground mine

\begin{tabular}{cccc}
\hline $\begin{array}{c}\text { Hole } \\
\text { Number }\end{array}$ & $\begin{array}{c}\text { Level } \\
\text { location }\end{array}$ & $\begin{array}{c}\text { Depth from earth’s } \\
\text { surface }(\mathrm{m})\end{array}$ & Temperature (C) \\
\hline 1 & $-587 \mathrm{~m}$ & 1017 & 26.7 \\
2 & $-587 \mathrm{~m}$ & 1017 & 26.9 \\
3 & $-647 \mathrm{~m}$ & 1077 & 26.9 \\
4 & $-647 \mathrm{~m}$ & 1077 & 27.1 \\
5 & $-707 \mathrm{~m}$ & 1137 & 28.4 \\
6 & $-707 \mathrm{~m}$ & 1137 & 28.5 \\
7 & $-767 \mathrm{~m}$ & 1197 & 29.9 \\
8 & $-767 \mathrm{~m}$ & 1197 & 29.9 \\
9 & $-827 \mathrm{~m}$ & 1257 & 30.0 \\
10 & $-827 \mathrm{~m}$ & 1257 & 30.5 \\
\hline
\end{tabular}




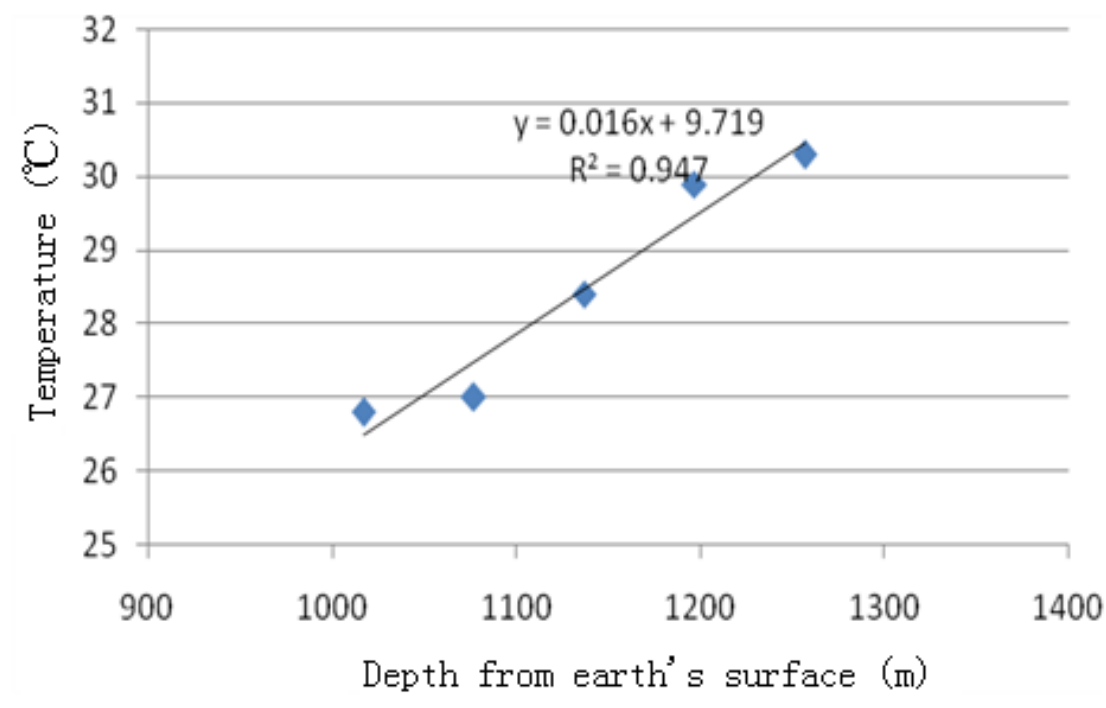

Figure 2 Relation between rock temperature and depth from earth’s surface

The figure show that the temperature increase with the depth, keeping good linear trend, the correlation coefficient $\mathrm{R}^{2}$ is 0.947 , which is high. The geothermal gradient is $1.6 \mathrm{C} / 100 \mathrm{~m}$ for Hongtoushan mine, which is less than the other metal mine in Liaoning province which is about $1.7-2.2 \mathrm{C} / 100 \mathrm{~m}$.

\section{Cooling depth of ventilation}

Cooling depth of ventilation reflect the influence ventilation air on the temperature of surrounding rock of tunnel, also reflect the different thermal conductivity properties of surrounding rock.

Method is based on: for the uniform rock in small scope, the original rock temperature is roughly equal on the same depth level. Once beyond the depth of the cooling, the temperature reached constant, the temperature is the original rock temperature.

Using the holes discussed before for testing. 2-3 holes in different types of rock are selected, with thermocouple probe plug into different depth, sealed with mud, and read temperature data after 24 hours. Change the location of thermocouple probe from tunnel surface (outside) into rock(inside). One data per day at one depth. From outside into inside, the temperature increase gradually. If the temperature no longer rise, the temperature data is the origin rock temperature at this depth. The depth is the Cooling depth of ventilation.The test result are shown in figure 3.

After digging tunnels in the original rock, if the wind temperature is lower than the original rock temperature, so the surrounding rock will transfer heat to the air in convection way, and the internal rock will transfer heat to the surrounding external rock cooled by wind in conduction way, at the same time, the deep rock is cooled to form cooling zone.

Figure 3 show that, with the depth from tunnel surface to internal rock increasing, the temperature of origin rock rise gradually. When the depth reach 20 meters from the tunnel surface, the temperature trend to stable. The temperature at the location 20 meters is the original rock temperature, and ventilation cooling depth is 20 meters. Also, the temperature at 25 meters depth tested in the paper is the original rock temperature. 


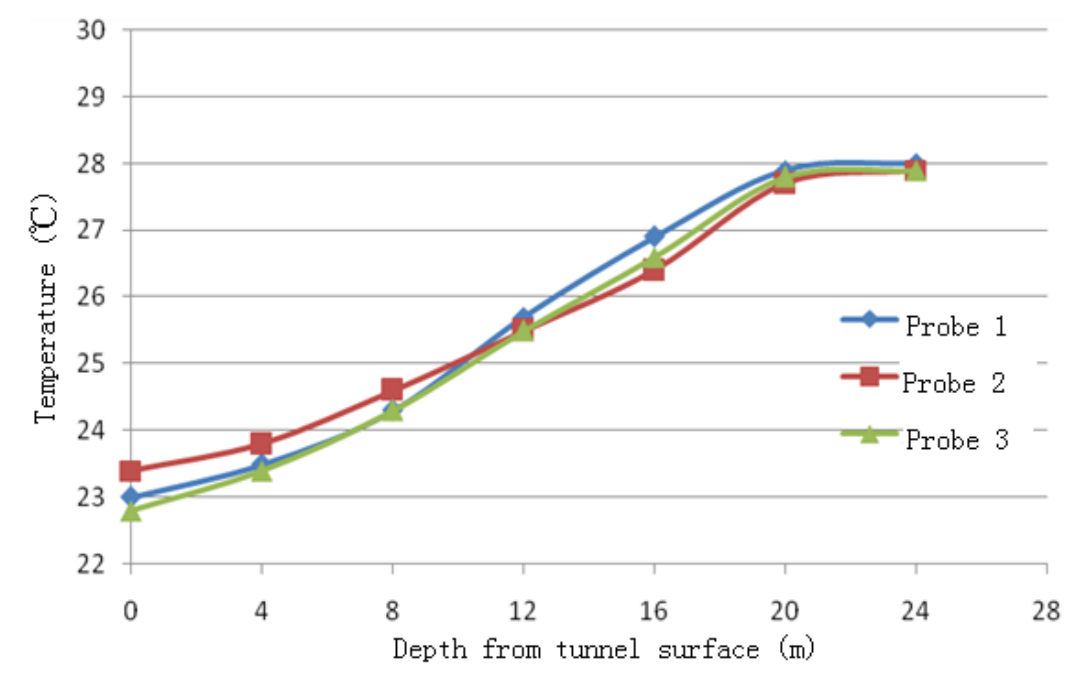

Figure 3 Relation between temperature and depth from tunnel surface

\section{Conclusion}

Based on the geothermal data test and analysis for Hongtoushan underground metal mine, conclusion listed in the follow:

1)the geothermal gradient is $1.6 \mathrm{C} / 100 \mathrm{~m}$, which is less than the metal underground mine in Liaoning province.

2)the Cooling depth of ventilation is 20 meters for Hongtoushan mine.

3)the origin rock temperature reach 30C at $-827 \mathrm{~m}$ level, which is serious, and should be paid atttion to.

\section{Acknowledgement}

It is a project supported by the National Science and technology support program(2013BAC01B02) and the national high technology research and development program (863 Program)

(2013AA065101).

\section{References}

[1]ZHANG Xiaolei, YANG Yunliang, XIAO Zhiguo,Temperature Measurement and Analysis of Original Rock in Chengjiao Coal Mine[J]. COAL TECHNOLOGY, 2011,12:76-78

[2]YANG Dingding, WANG Baishun, etc.,Ground temperature distribution and heat damage prevention of Huainan coal field[J]. CHINA MINING MAGAZINE, 2012,7:94-97

[3]LIU Kaihuim LIU Zhichao, applicaiton of geothermal temperature test on geothermal resources exploration[J]. Science-Technology Enterprise,2012, (2). In Chinese

[4]XIE Zhongpeng, SONG Xiaoyan, Regularities of Distribution of Ground Temperature and Study of Inverse Problem of High Temperature Mine[J]. ENERGY TECHNOLOGY AND MANAGEMENT, 2009,04. In Chinese

[5]GONG Yuling, WANG Liangshu, etc, Distribution Characteristics of Geotemperature field in Jiyang depression[J]. CHINESE JOURNAL OF GEOPHYSICS, 2003,05:652-658. In Chinese 